\title{
MULTIMEDIA TUTORIAL UNTUK MEMPERMUDAH PRONUNCIATION BAHASA INGGRIS MENGGUNAKAN METODE ALM KELAS VIII SMP
}

\section{Tri Ningsih, Zainul Abidin, Henry Praherdhiono}

Teknologi Pendidikan Fakultas Ilmu Pendidikan, Universitas Negeri Malang

Jalan Semarang 5 Malang 65145 0341-57400

triningsih116@gmail.com

\section{Article History}

Received: 05 November 2020, Accepted: 12 Maret 2021, Published: 20 November 2021

\begin{abstract}
Abstrak
Pengembangan ini memiliki tujuan mengembangkan dan menghasilkan multimedia berjenis tutorial yang bisa mempermudah pronunciation Bahasa Inggris peserta didik. Pengembangan ini memakai model Lee \& Owens. Hasil tanggapan ahli media dan ahli materi mendapatkankategori layak digunakan untuk multimedia pembelajaran. Berdasarkan hasil tanggapan peserta didik MTs kelas VIII E mendapatkan tanggapan positif. Saran ahli media dan materi berkenaan dengan multimedia berjenis tutorial, sedangkan peserta didik sebagai pengguna memberikan saran yang baik terhadap pemanfaatannya.
\end{abstract}

Keyword: Multimedia Tutorial; Pronunciation; Speaking

\begin{abstract}
The aim of this project is to create a tutorial-style multimedia that can help students with their English pronunciation. The Lee \& Owens model is used in this project. The responses of media experts and content experts result in categories that are suitable for multimedia learning. They received encouraging feedback based on the findings of the responses of students in MTs class VIII E. Students as consumers have good advice for how to use tutorial-type multimedia, as do media experts.
\end{abstract}

Keyword: Multimedia Tutorial; Pronunciation; Speaking 


\section{PENDAHULUAN}

Peningkatan mutu belajar dipengaruhi oleh beberapa faktor. Eyler dan Giles (2002) menyatakan bahwa media sangat mempengaruhi keefektifitan pembelajaran yang dimanfaatkan pendidik. Menurut Danim (2008) pemanfaatan teknologi dapat meningkatkan prestasi belajar karena adanya perantara dalam pembelajaran sehingga membantu kegiatan belajar di kelas, Hal ini senada Daryanto (2013) mengatakan bahwa fungsi media diantaranya untuk memperjelas pesan pembelajaran agar tidak terlalu verbalistis, menimbulkan semangat belajar peserta didik, serta merangsang minat, pikiran, dan perasaan peserta didik dalam pembelajaran. Penggunaan media bertujuan untuk memudahkan komunikasi dalam belajar (Smaldino, dkk 2011).

Multimedia berjenis interaktif adalah salah satu media yang dapat mendukung proses belajar sendiri. Karena multimedia berjenis interaktif menggunakan gabungan antara audio, teks, gambar, dan animasi/video (Mayer, 2005). Multimedia sangat banyak macamnya, salah satu multimedia interaktif yaitu Multimedia berjenis Tutorial. Multimedia interaktif juga dapat membangkitkan motivasi dalam belajar peserta didik karena dengan menggunakan media ini peserta didik tidak merasa bosan dan merasa senang.

Hasil pengembangan (Prastiwi, 2020) bahwa teknologi berbasis komputer belum digunakan secara sempurna dalam pembelajaran dan para peserta didik juga sudah memahami teknologi, sehingga mengakibatkan anjloknya minat belajar dan motivasi peserta didik. Sedangkan aktivitas pembelajaran menggunakan buku paket saja yang tidak cukup mencapai tujuan pembelajaran. Maka dari itu, multimedia tutorial dapat memberikan keadaan yang berbeda agar dapat memperbaiki pemikiran dan menambah pengetahuan baru peserta didik. Didalam tutorial peserta didik dapat menerapkan pengetahuan dan ide yang telah dimiliki secara mandiri dalam aktivitas belajar menggunakan media pembelajaran (Sudjana \& Rivai 2009).

Penyampaian materi didalam multimedia berjenis interaktif ini mengandung unsur bimbingan/pedoman pembelajaran yang dilengkapi adanya pembimbin dan alat tinjau oleh peserta didik. Tutorial dalam pembelajaran berbasis komputer seperti yang dinyatakan oleh Hermawan (2004) merupakan pembelajaran istimewa dengan pembimbing yang terkualifikasi dengan menggunakan aplikasi komputer yang berisi materi pelajaran dengan tujuan memberikan wawasan secara sempurna (mastery learning) kepada peserta didik mengenai materi atau bahan pengetahuan yang sedang dipelajari.

Kecakapan merupakan salah satu empat keahlian yang harus dikuasai dalam belajar bahasa, selain menulis, mendengarkan, dan menbaca. Menurut Bahadorfah (2014), dari keempat keahlian bahasa tersebut bicara dianggap hal paling dalam mendalami bahasa asing. Pada kemampuan speaking, peserta didik harus benar-benar sudah memahami Pronunciation dengan baik.

Pronunciation merupakan ketentuan dalam pelafalan kata bahasa Inggris atau logat seseorang melafalkan suatu kata, yang terpenting seseorang harus memiliki rasa percaya diri dalam memahami keahlian dalam berbicara. Penyebab yang mempengaruhi pelafalan Pronunciation baik, yaitu penutur asli, umur, pembawaan dan tekanan sosial (Demirezena \& Kotb, 2016). Motivasi/stimulus merupakan salah satu penyebab pencapaian kesuksesan belajar bahasa Inggris (Mubarok, 2019).

Teknik penggunaan dalam meningkatkan kecakapan Bahasa Inggris yaitu menggunakan ALM (Audio-Lingual Method). Berdasarkan hasil penelitian Mart (2013), yang menyatakan bahwa ALM (Audio-Lingual Method) bertujuan untuk mengembangkan kompetensi komunikasi peserta didik dengan memakai dialog dan latihan. Pengulangan dialog dan latihan akan menguatkan peserta didik merospon dengan cepat dan akurat dalam bahasa lisan. Selain itu, penelitian Haq (2014) menyatakan ALM (Audio-Lingual Method) mmiliki kedudukan penting dalam mengembangkan kecakapan peserta 
didik dalam waktu singkat. ALM ini merujuk pada teori belajar behavioristik, sehingga latihan dan menghafal materi merupakan teknik utama dalam aktivitas belajar.

Berdasarkan hasil observasi di MTsN 8 Ngawi memakai kurikulum 2013. Aktivitas belajar memakai kurikulum 2013 ini pembelajaran fokus terhadap peserta didik yang artinya peserta didik diwajibkan berperan aktif dalam proses pembelajaran (Anas, Soepriyanto, \& Susilaningsih, 2013). Menurut Winarno (2009) multimedia berperan penting dalam aktivitas belajar di masa saat ini, dikarenakan media dapat mencukupi semua cara berdaya guna dan berdaya tepat.

Permasalahan yang dihadapi peserta didik di MTsN 8 Ngawi antara lain (1) peserta didik sering mengucapkan Pronunciation salah contohnya kata around (e'round) diucapkan menjadi "aron", message (mesij) beberapa peserta didik mengucapkannya menjadi mesaj, sementara pronuncation kata massage artinya memijat sehingga terjadi salah paham antara pembicara dan pendengar, (2) kosa kata peserta didik sangat terbatas, (3) peserta didik masih berbicara terbata-bata karena kurangnya latihan. (4) penggunaan grammar sering terjadi kesalahan terutama pada kalimat tanya contoh kalimat " what your number phone?" kalimat tersebut merupakan contoh kesalahan fatal bagi pembicara tingkat peserta didik Kalimat yang benar adalah "what's your phone number?" (5) Gaya berbicara masih menggunakan gaya berbicara orang Indonesia yang diterjemahkan kedalam bahasa target (Bahasa Inggris) sehingga makna yang disampaikan sulit dimengerti bagi pendengar, harus mempunyai kecakapan yang benar dan baik agar bisa menerima pesan, (6) Buku dinilai kurang efisien dalam pembelajaran $s$ karena peserta didik tidak mendapatkan contoh langsung dan pendidik perlu mendemonstrasikan langsung artinya pembelajaran kurang efektif.

Adanya faktor yang dapat membuat kesulitan dalam Bahasa asing yaitu memahami pelafalan (Pronunciation) (Grant, 2010). Sebab itu, multimedia berjenis tutorial merupakan solusi untuk peserta didik Mts dalam melafalkan bahasa Inggris yang tepat. Media ini menyediakan file audio yang berisi frasa-frasa dan dialog-dialog yang berperan dalam kehidupan sehari-hari agar mudah diucapkan dan dipelajari. Rekaman audio/suara dapat mendukung peserta didik melatih pengucapan bahasa Inggris. Adanya media dapat membantu peserta didik dalam aktivitas belajar karena didalam media peserta didik bukan menjadi penutur yang asli tetapi menjadi penutur yang jelas dalam melafalkan (Atli \& Bergil, 2012).

\section{METODE}

Pengembangan ini menggunakan model Lee \& Owens (2004). Model ini memiliki tahapan-tahapan dalam prosesnya karena tersusun secara terstruktur dan setiap tahapan memiliki susunan yang tersusun dengan jelas.

Sesuai yang telah digambarkan, prosedur pengembangan Lee \& Owens (2004) tahap pertama yaitu tahap Penilaian dan Analisis (Assessment/Analysis) dibagi menjadi dua yaitu need assessment (penilaian kebutuhan) dan front-end analysis (analisis awal akhir). Need assessment dilakukan dengan wawancara langsung dan observasi dilakukan untuk melihat keadaan kondisi sekolah. Observasi dilakukan di MTsN 8 Ngawi. Wawancara dilakukan terhadap pendidik dan peserta didik bertujuan melihat kesenjangan antara keadaan nyata dan yang diinginkan. Front-end analysis meliputi analisis peserta didik, analisis teknologi, analisis tugas, analisis kejadian penting, analisis situasi, analisis tujuan, analisis media, dan analisis ketersediaan data.

Tahap kedua Design (Desain) yaitu menyusun desain rancangan pengerjaan produk/media yang akan dikembangkan seperti merancang spesifikasi media, merancang desain interface dan komponen lainnya seperti, audio dan gambar. Multimedia berbasis tutorial dilengkapi panduan pemakaian, Kompetensi Dasar, Standar kompetensi, indikator serta tujuan pembelajaran agar mudah memanfaatkan media interaktif. 


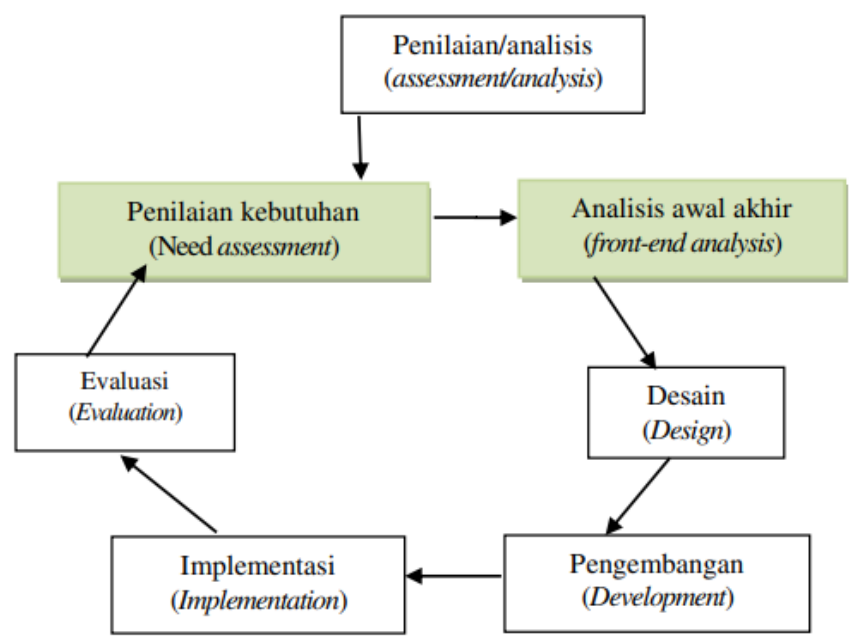

Gambar 1. Model Pengembangan Lee \& Owens (2004)

Tahap ketiga Development (Pengembangan), media ini memakai software pokok Articulate Storyline 3 dan bantuan perangkat lain. Sebelum diujicobakan kepeserta didik multimedia berjenis tutorial ini akan validasikan terlebih dahulu oleh ahli media dan ahli materi untuk melihat kelayakan multimedia berjenis tutorial yang dibuat. Kisi-kisi ahli media berjumlah 49 pernyataan berkenaan dengan media yang meliputi aspek Desain tampilan multimedia tutorial, Kemudahan Pengoperasian, Penggunaan interaksi serta Pemanfaatan. Sedangkan kisi-kisi ahli materi berjumlah 20 pernyataan berkenaan dengan materi meliputi aspek Kesesuaian Materi dengan SK dan KD, Keakuratan materi, Pendukung materi pembelajaran dan Kemutakiran materi. Selanjutnya teknik pengumpulan data dengan menyebarkan angket responden, soal pre-test dan post-test. Instrumen angket responden berjumlah 10 butir, sedangkan soal pre-test dan post-test masing-masing 20 butir soal. Kemudian disebarkan ke peserta didik kelas VIII E MtsN 8 Ngawi yang terdiri dari 29 peserta didik.

Disini juga menggunakan teknik Audio-Lingual Method (ALM) yaitu teknik pembelajaran bahasa Inggris yang diterapkan dalam mengembangkan keterampilan berbicara peserta didik. Dalam teknik ALM bahasa merupakan ucapan bukan tulisan, sekaligus menerapkan teori behaviorisme yang menjadikan bahasa sebagai sebuah perilaku. Apabila ALM diterapkan peserta didik akan terbiasa mengucapkan bahasa Inggris sebagai bagian perilaku keseharian mereka. ALM dilakukan dengan cara pendidik membaca dan mengulangi berbagai kata dan kalimat yang disiapkan dimedia berupa audio/suara atau file-file rekaman materi kemudian peserta didik tinggal menirukannya. Guru juga mengulangi beberapa kali sampai peserta didik dirasa mampu mengucapkan Bahasa Inggris seperti penuturan bahasa aslinya.

\section{HASIL}

Dari hasil tanggapan dari ahli media dan ahli materi serta uji coba peserta didik disajikan pada tabel 1 , 2 dan 3.

Tabel 1. Hasil tanggapan ahli media

\begin{tabular}{|c|c|c|c|c|}
\hline Aspek & Jumlah butir & Sangat setuju & Setuju & Rata-rata \\
\hline Kualitas teknis & 8 & 6 & 2 & 3,7 \\
\hline Penggunaan interaksi & 5 & 5 & 0 & 4 \\
\hline Kemudahan pengoperasian & 5 & 4 & 1 & 3,8 \\
\hline Pemanfaatan & 28 & 25 & 3 & 3,8 \\
\hline
\end{tabular}

Berdasarkan tabel 1 menyajikan hasil tanggapan ahli media terhadap aspek kualitas teknis diperoleh rata-rata nilai 3,7. Dalam aspek pemanfaatan interaksi memperoleh rata-rata nilai 4 . Kemudian aspek kemudahan pengoperasian dengan nilai rata-rata 3,8 dan aspek pemanfaatan dengan nilai rata-rata 3,8 dari total 46 pernyataan. 
Tabel 2. Hasil tanggapan ahli materi

\begin{tabular}{lcccc}
\hline Aspek & Jumlah butir & Sangat setuju & Setuju & Rata-rata \\
\hline Kesesuaian Materi Dengan SK Dan KD & 8 & 3 & 5 & 3,3 \\
Keakuratan Materi & 3 & 1 & 2 & 3,3 \\
Pendukung Materi & 5 & 4 & 1 & 3,8 \\
Kemutakiran Materi & 4 & 3 & 1 & 3,7 \\
\hline
\end{tabular}

Berdasarkan tabel 2 menyajikan hasil tanggapan ahli materi dalam aspek kesesuaian materi dengan SK dan KD memperoleh rata-rata nilai 3,3. Dalam aspek keakuratan materi mendapat rata-rata nilai 3,3. Kemudian aspek keakuratan materi memperoleh nilai rata-rata 3,8 dan aspek kemutakiran materi dengan nilai rata-rata 3,7 dari total 46 pernyataan.

Tabel 3. Hasil tanggapan peserta didik/audiens

\begin{tabular}{lcccc}
\hline Aspek & Butir pernyataan & Jumlah siswa & Sangat setuju & Setuju \\
\hline Media & 1 & 29 & 29 & 0 \\
& 2 & 29 & 29 & 0 \\
& 3 & 29 & 18 & 11 \\
& 4 & 29 & 29 & 0 \\
& 5 & 29 & 17 & 12 \\
\hline Materi & 6 & 29 & 16 & 13 \\
& 7 & 29 & 16 & 0 \\
\hline Pembelajaran & 8 & 29 & 29 & 0 \\
& 9 & 29 & 29 & 15 \\
\hline
\end{tabular}

Berdasarkan tabel 3 menunjukkan jumlah 29 audiens/peserta didik, dengan jumlah penyataan 10 item meliputi 5 pernyataan pada aspek media, 3 pernyataan pada aspek materi dan 2 pernyataan pada aspek pembelajaran. Pada butir pernyataan 1 kategori sangat setuju berjumlah 29 peserta didik, butir 2 kategori sangat setuju berjumlah 29 peserta didik, butir 3 kategori sangat setuju berjumlah 11 peserta didik dan setuju 11 peserta didik, butir 4 kategori sangat setuju berjumlah 29 peserta didik, butir 5 diperoleh kategori sangat setuju berjumlah 17 peserta didik dan setuju 11 peserta didik, butir 6 diperoleh kategori sangat setuju berjumlah 16 peserta didik dan setuju 13 peserta didik, butir 7 diperoleh kategori sangat setuju berjumlah 16 peserta didik dan setuju 13 peserta didik, butir 8 kategori sangat setuju berjumlah 29 peserta didik, butir 9 kategori sangat setuju berjumlah 29 peserta didik, butir 10 kategori sangat setuju berjumlah 14 peserta didik dan setuju 15 peserta didik.

Selanjutnya dilihat dari hasil belajar melalui kegiatan pre-test dan post-test yang dikerjakan pada 29 peserta didik terdapat peningkatan rata-rata nilai dari 72, 41 menjadi 93,1. Terdapat 25 peserta didik yang mengalami kenaikan nilai, sedangkan 4 peserta didik lainya belum mengalami kenaikan nilai. Dilihat dari hasil analisis keberhasilan tes belajar membuktikan bahwa 25 peserta didik mudah mengoperasikan multimedia tutorial dalam aktivitas belajar, sedangkan 4 peserta didik lainnya masih merasa kesulitan mengoperasikan multimedia berbasis tutorial dalam kegiatan belajar. Dari uraian tyang dipaparkan dapat disimpulkan bahwa multimedia berbasis tutorial ini layak dimanfaatkan peserta didik sebagai media pembelajaran.

\section{PEMBAHASAN}

Media merupakan cara penyebaran konsep yang digunakan orang, sehingga ide itu sampai pada penerima (Sihkabuden, 2015). Multimedia adalah perpaduan bermacam-macam media seperti audio, animasi, gambar, teks, video dan lain lain, kemudian disatukan berbentuk file digital dengan bantuan komputer yang berguna untuk mengantarkan pesan atau informasi (Munir, 2015). Secara umum pemakaian multimedia berjenis interaktif dalam pembelajaran yaitu proses pembelajaran terlihat menarik bagi peserta didik, selain itu pembelajaran menjadi interaktif dan waktu mengajar lebih sedikit atau pendek, pemahaman peserta didik dalam belajar suatu materi dapat ditingkatkan karena bisa dilakukan secara mandiri dengan dilakukan dimana saja dan kapan saja. Multimedia berjenis 
interaktif dapat menciptakan belajar yang interaktif, menarik/menyenangkan dan tidak membosankan, karena media dibuat dengan menggunakan teknologi berbasis komputer sehingga dapat menyampaikan materi secara tekstual, audio dan visual (Rosyida, 2017).

Produk multimedia berjenis tutorial ditanggapi ahli media dan ahli materi, terdapat 46 pernyataan untuk ahli media dan 20 pernyataan untuk ahli materi yang berkaitan dengan multimedia berbasis tutorial. Dari hasil tanggapan ahli media menghasilkan data kuantitatif, yaitu 46 pernyataan terdiri dari 39 pernyataan kategori Sangat Setuju dengan bobot nilai sebesar (4) dan terdapat 7 pernyataan kategori Setuju dengan bobot nilai sebesar (3) meliputi beberapa aspek yaitu desain tampilan multimedia tutorial terdapat 6 pernyataan dengan kategori Sangat Setuju dan 2 pernyataan dengan kategori Setuju memperoleh nilai rata-rata 3,7, aspek Kemudahan Pengoperasian terdapat 5 item pernyataan dengan kategori Sangat Setuju dengan nilai rata-rata 4, aspek Penggunaan interaksi mendapat 4 pernyataan dengan kategori Sangat Setuju dan 1 item pernyataan dengan kategori Setuju memperoleh n nilai rata-rata 3,8, aspek Pemanfaatan mendapat 25 pernyataan dengan kategori Sangat Setuju dan 3 pernyataan dengan kategori Setuju memperoleh nilai rata-rata 3,8. Sedangkan hasil tanggapan ahli materi mengasilkan data kuantitatif, yaitu 20 butir pernyataan yang terdiri dari 11 pernyataan kategori Sangat Setuju dengan bobot sebesar (4) dan terdapat 9 pernyataan kategori Setuju dengan bobot sebesar (3) meliputi beberapa aspek yaitu yaitu pada aspek kesesuaian materi dengan SK dan KD terdapat 3 pernyataan dengan kategori sangat setuju dan 5 pernyataan dengan kategori setuju dengan nilai rata-rata 3,3, aspek keakuratan materi terdapat 1 item pernyataan dengan kategori sangat setuju dan 2 item pernyataan dengan kategori setuju memperoleh nilai rata-rata 3,3, aspek pendukung materi terdapat 4 item pernyataan yang kategori sangat setuju dan 1 item pernyataan dengan kategori setuju memperoleh nilai rata-rata 3,8. aspek kemutakiran materi terdapat 3 pernyataan dengan kategori sangat setuju memperoleh rata-rata 3,7. Dilihat dari data hasil uji validasi oleh ahli media, dapat diinterpretasikan bahwa multimedia tutorial ini layak digunakan dalam proses pembelajaran.

Ahli media dan materi memberikan tanggapan positif bahwa media layak dapat digunakan untuk proses pembelajaran. Sedangkan ujicoba pemakaian dilakukan peserta didik MTS kelas VIII E dengan hasil tanggapan positif. Berdasarkan aspek-aspek pernyataan ahli media terdapat 46 pernyataan dapat diringkas bahwa terdapat 39 pernyataan menjawa sangat setuju dan 7 pernyataan menjawa setuju. Pada aspek pernyataan ahli materi terdapat 11 pernyataan menjawab sangat setuju dan 9 pernyataan menjawab setuju. Sedangkan hasil ujicoba dari 29 peserta didik terdapat 4 peserta didik menjawab sangat setuju sedangkan 25 peserta didik menjawab setuju dan sangat setuju.

Pada pengembangan multimedia model tutorial juga dilengkapi panduan pemakaian, Kompetensi Dasar, Standar kompetensi, indikator serta tujuan pembelajaran agar mudah memanfaatkan media interaktif. Multimedia tutorial dapat dioperasikan dengan mengklik tombol-tombol interaktif yang disediakan disetiap halaman slide. Tombol-tombol ini dirancang dengan tujuan agar memudahkan perpindahan slide agar mempermudah pengguna dalam mengoperasikan.

Multimedia model tutorial yang dibuat berkriteria mudah dioperasikan, karena penggunaan konten-konten multimedia model tutorial ini sangat berguna bagi peserta didik dalam menambah wawasan terutama simulasi interaktif selain materi yang ditampilkan. Hal ini selaras dengan adanya simulasi interaktif peserta didik membutikan sendiri dan melihat hasilnya secara interaktif. Format media tutorial juga disempurnakan adanya pertanyaan atau quis yang wajib dijawab oleh pengguna. Apabila jawaban yang diperoleh benar, maka pengguna dapat melanjutkan materi berikutnya. Apabila jawaban salah, maka pengguna harus mempelajari kembali konsep materi tersebut.

Hasil pengembangan dari Umroh (2019) menyatakan multimedia model tutorial membantu mengatasi masalah rendahnya minat baca yang dialamai anak ADHD. Terbukti hasil tanggapan ahli media sebesar $82.2 \%$, ahli materi sebesar $95.5 \%$ dan ahli praktisi sebesar 92.5\%. dapat dilihat dari 
kegiatan hasil nilai pre-test dan post-test yang mengalami kenaikan dari nilai 70 pada kegiatan pre-test menjadi 90 pada kegiatan post-test.

Demikian pula pada pengembangan Wardani (2019) multimedia model tutorial mata pelajaran IPA pokok bahasan sistem tata surya kelas VII layak dimanfaatkan dalam kegiatan pembelajaran. Karena terbukti dari tanggapan ahli media sebesar $90.4 \%$, ahli materi sebesar $90.3 \%$, dan hasil uji kelompok kecil dan besar yang mengahasilkan media layak digunakan dalam kegiatan pembelajaran.

Hasil pengembangan Aktoriawan (2020) bahwa multimedia tutorial mata pelajaran IPA sistem gerak tubuh manusia dinyatakan layak dalam meningkatkan hasil belajar peserta didik. Terbukti dari tanggapan ahli media sebesar $98.75 \%$, ahli materi sebesar $98.75 \%$. Sedangkan ujicoba peserta didik diperoleh persentase $97,5 \%$ sehingga dinyatakan bahwa multimedia model tutorial layak digunakan dalam aktivitas belajar.

Multimedia model tutorial ini menggunakan teknik ALM yaitu teknik pembelajaran bahasa Inggris yang diterapkan dalam mengembangkan keterampilan berbicara peserta didik. Apabila ALM diterapkan maka peserta didik akan terbiasa mengucapkan bahasa Inggris sebagai bagian keseharian mereka. ALM dilakukan dengan cara pendidik membaca dan mengulangi berbagai kata dan kalimat yang disiapkan dimedia berupa audio/suara atau file-file rekaman materi kemudian peserta didik tinggal menirukannya. Guru juga mengulangi beberapa kali sampai peserta didik dirasa mampu mengucapkan Bahasa Inggris seperti penuturan bahasa aslinya.

Dalam pembelajaran materi Speaking dengan tema Teks Interpersonal ini guru memakai media medel tutorial dengan menggunakan Teknik ALM. Disini guru dituntun kreatif dalam aktivitas pembelajaran, sehingga pembelajaran tidak berjalan monoton. Pada pelafalan kalimat dan kata dilakukan dengan mengulangi menghafal kalimat sampai peserta didik menguasai dan mampu menggunakannya secara spontan.

Penerapan ALM ini bisa mempermudah peserta didik dengan mendengar dan memahami pelafalan/pengucapan orang lain dalam percakapan sehari-hari. Selain itu, peserta didik dapat melafalkan kata-kata atau kalimat yang berhubungan dengan Bahasa inggris cocok dengan grammar.

Alessi S. M., Trollip. S. R., (2001) menjelaskan bahwa tutorial diajukan untuk memenuhi dua fase pertama dan biasanya tidak mengikut sertakan praktik atau penilaian kegiatan belajar. Bebarapa tutorial tidak membimbing peserta didik melalui informasi, tetapi hanya menyampaikan saja. Seharusnya agar tutorial terlihat baik sebaiknya menggunakan keduanya yang berisi bimbingan dan presentasi. Hal ini didukung pengembangan yang dilaksanakan (Sriadhi S, Gultom S, Restu R, dan Simarmata J, 2017) menyatakan bahwa multimedia berbasis tutorial memiliki pembelajaran multimedia tutorial memiliki dampak positif dan linear terhadap penguasaan nilai peserta didik. Multimedia berjenis tutorial ini berisi penjelasan yang berkenaan dengan materi, dan juga latihan soal disetiap selesai penyajian satu materi. Konten didalam media berisi gabungan antara gambar, teks, video, audio dan animasi. Peserta didik memiliki perantara didalam media yaitu dibimbing PC untuk melakukan beberapa kegiatan yaitu membaca, mendengarkan dan menonton. Multimedia model tutorial materinya dikemas dalam Bahasa yang komunikatif agar dapat membantu siswa dalam belajar.

Dari beberapa penelitian yang telah dilakukan, jadi diperoleh kesimpulan bahwa multimedia berjenis tutorial menunjukkan hasil produk yang bagus apabila dimanfaatkan selaras dengan prosedur yang telah dicantumkan karena tutorial ini mencakup adanya tampilan awal, isi materi serta timbal balik dari multimedia berjenis tutorial (Alessi \& Trollip, 2001). Dalam pengembangan multimedia berjenis tutorial ini bertujuan sepenuhnya untuk menggantikan pendidik dalam aktivitas belajar. Akan tetapi, pada hasil ujicoba yang sudah dilaksanakan bahwa dalam pengoperasian multimedia berjenis tutorial peserta didik masih memerlukan pengendalian dari pendidik. Sebenarnya peran pendidik disini hanya memastikan apakah peserta didik benar-benar belajar dengan disiplin sampai menyelesaikan 
semua tahapan isi materi pada multimedia berjenis tutorial atau tidak. Selain itu, itu multimedia berjenis tutorial mampu mempermudah peserta didik untuk mengikuti dan mempraktikkan prosedur dalam kegiatan pembelajaran tutorial agar siswa semakin mandiri dan pendidik akan dipermudah dalam kegiatan menjelaskan panduan kepada peserta didik (Putra, Kesiman and Darmawiguna, 2013). Multimedia berjenis tutorial didesain secara interaktif menarik serta mudah dioperasikan.

\section{SIMPULAN}

Berdasarkan tanggapan ahli media dan ahli materi multimedia berjenis tutorial dinyatakan layak dimanfaatkan sebagai multimedia pembelajaran. Sedangkan ujicoba penggunaannya dilaksanakan peserta didik MTSN kelas VIII E dengan hasil tanggapan positif. Saran ahli media dan materi berkenaan dengan multimedia berjenis tutorial, sedangkan peserta didik sebagai pengguna media memberikan saran baik terhadap pemanfaatannya. Maka berdasarkan kategori yang ditetapkan kriteria kemudahan pronunciation materi speaking tergolong Tinggi. Dapat disimpulkan bahwa peserta didik lebih mudah dan tertarik melafalkan bahasa inggris menggunakan multimedia berjenis tutorial daripada memanfaatkan buku teks.

\section{DAFTAR RUJUKAN}

Aktoriawan, B., Sulton., Sulthoni. (2020). Pengembangan Multimedia Tutorial Sistem Gerak Tubuh Manusia Untuk Memfasilitasi Peserta didik Belajar Di Rumah. Jurnal Kajian Teknologi Pendidikan, 3(3) 317-329.

Alessi, S. M \& Trollip, S. R. (2001). Multimedia For Learning: Methods And Development. 2nd ed. USA: Pearson Education.

Anas, A. M., Soepriyanto, Y., \& Susilaningsih. (2019). Pengembangan Multimedia Tutorial Topografi Jaringan Untuk SMK Kelas X Teknik Komputer Dan Jaringan. Jurnal Kajian Teknologi Pendidikan, 1(4) 307-314.

Bahadorfar, M. (2014). Technology In Teaching Speaking Skill. Acme International Journal of Multidisciplinary Research. 2 (4), 9-13.

Danim, S. (2008). Media Komunikasi Pendidikan Pelayan Profesional Pembelajaran dan Mutu Hasil Belajar. Jakarta: PT. Bumi Aksara.

Daryanto. (2013). Media Pembelajaran. Yogyakarta: Gaya Media.

Demirezena, Mehmet \& Kotb, Esma. (2016). Collegial Reactions to Faulty Pronunciation of Teachers in Relation to English Language Teaching. Procedia - Social and Behavioral Sciences. No. 232 $471-478$

Eyler, J. (2002). Reflection: Linking service and learning-Linking students and communities. Journal of issues, 58(3).

Grant, L. (2010). Well Said Pronunciaation for Clear Communication. Boston: Heinle \& Heinle, a Division of Thomson Learning, inc.

Haq, N. (2014). An Analysis of the Effects of Audio - Lingual Method of Teaching on the Listening \& Speaking Skills of Students. International Journal For Teachers Of English. 4 (1), 105-176.

Heinich, Molenda, Russel. (1996). Instructional Media and New Techologies Of Instruction, Englewood Cliffs, N. J: Prentice-Hall.

Hermawan, A. H et al. (2004). Pengembangan Model Pembelajaran Teori Dan Praktek. Bandung: Jurusan Kurikulum Dan Teknologi Pendidikan DIP UPI.

Isil. Atli, A. S. (2012). The Effect Of Pronunciation Instruction On Students' Overall Speaking Skills. Procedia-Social and Behavioral Sciences, 46: 3665 - 3671.

Lee, William W \& Owens, Diana L (2004). Multimedia-Based Instructional Design. San Fransisco: Pfeiffer. 
Mart, C. T. (2013). The Audio-Lingual Method: An Easy way of Achieving Speech. International Journal of Academic Research in Business and Social Sciences. 3 (12), 63-65.

Mubarok, T.A. (2019). Motivasi belajar bahasa inggris pada peserta didik Madrasah Aliyah Darul Mutaállimin Sugihwaras Patianrowo Nganjuk. Briliant: Jurnal Riset dan Konseptual, 4 (1): 118124.

Munir, (2015). Multimedia Konsep \& Aplikasi dalam Pendidikan. Bandung: CV Alfabeta.

Rosyida, S. (2017). Multimedia Interaktif sebagai Media Pembelajaran tentang Pengenalan Vitamin yang Terkandung di Dalam Buah. Jurnal Teknik Informatika STMIK Antar Bangsa, 3, 17-23.

Sadiman, Arief S, dkk. (2010). Media Pendidikan, Pengertian, Pengembangan dan Pemanfaatannya. Jakarta: PT. Raja Grafindo Persada.

Sihkabuden. (2015). Media Pembelajaran. Malang: Fakultas Ilmu Pendidikan.

Smaldino, S., Deborah, L. James, D. (2011). Intructional Technology and Media for Learning: Teknologi Pembelajaran dan Media untuk Belajar. Jakarta: Kencana.

Sriadhi, S., Gultom, S., Restu, R., Simarmata, J. (2017). The Effect of Tutorial Multimedia on the Transformator. International Symposium on Materials and Electrical Engineering (ISMEE) 384 (1) 012059.

Umroh, N. S., Edi, E. P \& Ulfa, S. (2019), Multimedia Tutorial Untuk Menumbuhkan Minat Baca Anak ADHD (Attention Deficit Hyperactivity Disorder). Jurnal Kajian Teknologi Pendidikan, 2(1) $45-52$.

Putra, G. T. S., Kesiman, M. W. A., \& Darmawiguna, I. G. M. (2013). Pengembangan Media Pembelajaran Dreamweaver Model Tutorial Pada Mata Pelajaran Mengelola Isi Halaman Web Untuk Peserta didik Kelas XI Program Keahlian Multimedia Di SMK Negeri 3 Singaraja. Jurnal Nasional Pendidikan Teknik Informatika (JANAPATI), 2(2), 125.

Prastiwi, D. N., Setyosari, P., Husna, A. (2020) Pengembangan Multimedia Tutorial Sebagai Suplemen Pada Mata Pelajaran Kimia Asam Dan Basa Kelas XI. JINOTEP, 6(2): 69-80.

Wardani, K. S., Setyosari, P., \& Husna, A. (2019). Pengembangan Multimedia Tutorial Mata Pelajaran IPA Pokok Bahasan Sistem Tata Surya Kelas VII MTS Raudlatul Ulum. Jurnal Kajian Teknologi Pendidikan, 2(1), 23-29. 